Case research

\title{
Lenovo Acquired Motorola Mobility in a Bipolar World of Mobile phone makers
}

\author{
Article history: \\ Received:16 November 2016 \\ Sent for revision: 17 December 2016 \\ Received in revised form: 7 February 2017 \\ Accepted: 24 February 2017 \\ Available online: 1 July 2017
}

\begin{abstract}
This paper presents an analysis of key points of Lenovo and Motorola deal such as approval of the deal by regulatory bodies in the United States and China, pricing and payment terms of the deals, positive and negative side of the deal for Google and Lenovo in the present context and in future, impact on the smartphone markets in China and world, possibilities of Lenovo making it a repeat of acquiring ThinkPad business of IBM during 2004 or will get rid of Motorola like Google. The analysis is based on qualitative and time series quantitative data compiled from different sources. The quantitative data are mainly consists of changes in different parameters of mobile phone business before and after the acquisition of Motorola Mobility by Lenovo. The quantitative data are analyzed with respect to different growth parameters of mobile phone business of major manufacturers. Research paper also attempts to find answers to few specific research questions with respect to impact on eco-systems of Google and Lenovo technologies. Based on analysis, it is inferred that becoming a successful organization in device manufacturing in an industry which is highly competitive, work with low margins, and maturing is becoming difficult with passing time.
\end{abstract}

Keywords: Motorola Mobility, Lenovo, Cloud technologies, Patents, Moto Brand, and Smartphone.

\footnotetext{
${ }^{1}$ Management Development Institute,India. knpsingh@gmail.com 
Singh N.P.: Lenovo Acquired Motorola Mobility in a Bipolar World of Mobile phone...

\title{
Preuzimanje Motorola Mobiliti od strane Lenova u bipolarnom svetu proizvođača mobilnih telefona
}

\begin{abstract}
Apstrakt: U ovom radu predstavljena je analiza ključnih tačaka dogovora kompanija Lenovo i Motorola kao što su odobravanje dogovora od strane regulatornih tela u Sjedinjenim Američkim Državama i Kini, cenovni uslovi $i$ uslovi plaćanja ugovora, pozitivna i negativna strana ugovora za Google i Lenovo u sadašnjem kontekstu i u budućnosti, uticaj na tržišta pametnih telefona u Kini i svetu, mogućnosti kompanije Lenovo da ponovi kupovinu ThinkPad poslovanja IBM-a tokom 2004. godine ili odbacivanje Motorole kao što je Google uradio. Analiza se zasniva na kvalitativnim i vremenskim serijama kvantitativnih podataka prikupljenih iz različitih izvora. Kvantitativni podaci uglavnom se sastoje od promena u različitim parametrima poslovanja sa mobilnim telefonima pre i nakon kupovine kompanije Motorola Mobility od strane kompanije Lenovo. Kvantitativni podaci se analiziraju u odnosu na različite parametre rasta poslovanja sa mobilnih telefona glavnih proizvođača. Istraživački rad takođe pokušava da pronađe odgovore na nekoliko specifičnih istraživačkih pitanja u vezi sa uticajem Google i Lenovo tehnologija na ekosisteme. Na osnovu analize, zaključuje se da postizanje pozicije uspešne organizacije u proizvodnji uređaja u industriji koja je visoko konkurentna, radi sa malim maržama, a zrelost postaje teška tokom vremena.
\end{abstract}

Ključne reči: Motorola Mobility, Lenovo, Cloud tehnologije, patenti, Moto brend, pametni telefoni

\section{Introduction}

Motorola was founded on September 25, 1928 and was divided in to two public companies (Motorola Mobility and Motorola Solutions) on January 4, 2011. Just after the division of Motorola, Google bought Motorola Mobility for US $\$ 12.5$ billion to become consumer gadgets maker from a search-andsoftware company. This deal is similar to Microsoft and Nokia in many ways (Singh.(2014a), Fishman (2014)).With Motorola mobility, Google became both hardware and software company. Google announced that it will create wonderful devices (smartphone) to be used by the people around the world. In addition, Google got more than 17,000 Motorola Mobility's patents and an additional 7500 patents of Motorola Mobility that are not yet approved (Goldman (2012)). But Google could not revive the company to make wonderful devices and decided to leave Motorola Mobility for Lenovo, a personal technology company and the world's largest PC vendor with a worth of US $\$ 47$ billion as on 20.02.15 (US\$ 30 Billion on 18.09.12). During the period of ownership of Motorola Mobility, Google sold many important units of 
Singh N.P.: Lenovo Acquired Motorola Mobility in a Bipolar World of Mobile phone...

Motorola Mobility before Lenovo deal. The details of these deals of Google are compiled in table 3.

Continuing its more than decade old strategy as evident from data given in table 1 and table 2, Lenovo acquired Motorola Mobility from Google and x_86 server businesses from IBM during 2014 (Singh (2015a)). Lenovo expects every time repeat of the success of acquisition of ThinkPad business of IBM which made Lenovo, the world leader in personal computers in 2012. However these acquisitions were much less in dollar value and publicity in comparison to Microsoft acquiring Nokia's mobile handset business (Singh (2014a)) and Verizon acquiring stake of Vodafone (Singh (2014b)). Motorola Mobility deal is very important for Lenovo and its Smartphone business as well as Smartphone business of competitors. If Lenovo succeed it will encourage Lenovo to buy more loss making companies in days to come. In addition, it will help in making Lenovo a strong brand in the world. Success will help Lenovo in meeting almost all requirements of its enterprise customers. On the other if it fails it will put break on present inorganic growth model of Lenovo and will have a negative impact on its Smartphone business as well as its other businesses.

Keeping in view, the importance of the deal to smartphone segment of highly competitive electronic industry, this paper attempts to analyze the impact of the deal on Lenovo smartphone business in the next few quarters. In addition, research paper presents details of the deal, reasons for Lenovo to acquire Motorola Mobility, positive side of the deal for Google, impact of deal on Lenovo during 2014 and 2015 with specific reference to retention of workforce, product and process innovation, other members of ecosystem etc. The research paper also included a section of research methodology giving details of 10 research questions. Research paper presents answers of these research questions based on the analysis of qualitative and quantitative secondary data compiled from different secondary sources. Research paper ends with concluding remarks.

\section{Research Methodology}

Research methodology of the research paper can be termed as exploratory in nature since it is based on secondary piecemeal data collected from many sources. On the other hand, research paper contains sufficient amount of historical as well as current data which is sufficient to conclude or answer listed research questions to large extent, therefore, methodology can be termed as exploratory cum descriptive in nature. The conclusions are drawn based on both qualitative and quantitative secondary data collected from the various resources mainly internet (websites of main stakeholders and market 
Singh N.P.: Lenovo Acquired Motorola Mobility in a Bipolar World of Mobile phone...

research companies). These conclusions need further examination with the availability of more data on the subject in near future. The analysis of the research paper can be termed as similar to content analysis, event analysis, and trend analysis. Analysis is an attempt to generate possible answer to the following research questions and draw meaningful conclusions.

Research Question 1: Will Lenovo repeat success of IBM's ThinkPad business deal in case of Motorola Mobility?

Research Question 2: Is synergy trap hypothesis true in acquisition of Motorola Mobility business?

Research Question 3: Will it help Lenovo to acquire more small loss making units if any and help Lenovo to innovate in smartphone manufacturing technology and processes?

Research Question 5: Is inorganic expansion path better for faster growth in high tech electronic industry such as smartphone?

Research Question 6: Will Lenovo retain the Motorola Mobility and brand Motorola in the long run along with brand Lenovo?

Research Question 7: Will huge local Chinese market of smartphone help Lenovo to repeat the success of ThinkPad business?

Research Question 8: Will Lenovo be a test case for cash rich Chinese companies?

Research Question 9: Will laying-off large number of employees lead to down fall of the Lenovo reputation in near future?

Research Question 10: Is it strategic tie up with Google and US major carriers and nothing else? (Perez (2014)).

Further, analysis includes data of many events linked to the deal. These events includes (i) success of ThinkPad PC business acquisition, (ii) approval of the deal by regulatory agencies in China and USA, (iii) acquisition of two companies within short span of time, (iv) growth and decline of smartphones of Lenovo, ( $v$ ) inorganic path of success (vi) cost cutting measures of Lenovo in the form of laying off manpower, (vii) movement of stock prices of Motorola as well as Lenovo, (viii) announcement of starting smartphone production in India for both brands (Motorola and Lenovo) by Lenovo, (ix) investment in new projects such as Tango smartphone, $(x)$ reduction in $\mathrm{PC}$ sales across the world, (xi) closing of offices by Lenovo, (xii) growth in sales during 2014 just after acquisition of Motorola Mobility, (xiii) changes in Lenovo emerging markets centric strategy, (xiv) Lenovo policies of being global leader in all segments, (xv) announcement of new line of products by Lenovo etc. Analysis and discussion began with recent deals of Lenovo, starting with acquisition of ThinkPad business by Lenovo. It is followed by details of the deal of Motorola Mobility, reasons for Lenovo to acquire Motorola Mobility, positive side of the deal for Google, impact of the deal on Lenovo during 2014 and 2015, impact 
Singh N.P.: Lenovo Acquired Motorola Mobility in a Bipolar World of Mobile phone...

on ecosystem of smartphone industry etc. The research paper also included events of 2016. Research paper ends with possible answer to research questions and concluding remarks emphasizing future scenario for Lenovo.

\section{Results and discussion}

\subsection{Lenovo Deals of Past}

The success of Lenovo in the past decade can be termed as strategic fit in the context of its growth oriented business policies which are based on both process and product innovation, and its ability to integrate asset of acquired business (products, processes, technology, and manpower) with the existing one. Singh (2015a) compiled all deals in chronological way.

Table 1: Comparison of Payment Terms of 3 Deals of Lenovo

\begin{tabular}{|c|c|c|c|c|}
\hline Parameters & Motorola Mobility & $\begin{array}{c}\text { IBM ThinkPad PC } \\
\text { Business }\end{array}$ & $\begin{array}{c}\text { IBM's x86 Server } \\
\text { Business }\end{array}$ & Source \\
\hline Value & US\$ 2.91 Billion & US \$ 1.75 Billion & US \$ 2.1 Billion & \multirow[b]{3}{*}{$\begin{array}{l}\text { Barinka } \\
(2014), \\
\text { Spooner } \\
\text { and } \\
\text { Kanellos } \\
(2014), \\
\text { Perez } \\
(2014), \\
\text { Burns } \\
(2014)\end{array}$} \\
\hline Year & 2014 & 2004 & 2014 & \\
\hline Payment & $\begin{array}{l}\text { US\$ } 660 \text { Million in } \\
\text { Cash + US } \$ 750 \\
\text { Million in Lenovo } \\
\text { stock + US } \$ 1.5 \\
\text { Billion in deferred } \\
\text { consideration in } \\
\text { the form of three- } \\
\text { year interest-free } \\
\text { promissory note + } \\
\text { a cash } \\
\text { compensation of } \\
\text { US } \$ 228 \text { million }\end{array}$ & $\begin{array}{l}\text { US\$ } 650 \text { Million in } \\
\text { cash }+\$ 600 \text { million } \\
\text { in securities + IBM } \\
\text { will have } 18.9 \% \\
\text { stake in Lenovo \& } \\
\text { will remain Lenovo's } \\
\text { second-largest } \\
\text { shareholder. }\end{array}$ & $\begin{array}{l}\text { US } \$ 1.80 \text { Billion } \\
\text { in cash }+\$ 280 \\
\text { million of its } \\
\text { stock to IBM. }\end{array}$ & \\
\hline Objective & $\begin{array}{l}\text { To be major player } \\
\text { in smartphone } \\
\text { segment of } \\
\text { lucrative markets }\end{array}$ & $\begin{array}{l}\text { To have long term } \\
\text { relationship with } \\
\text { IBM. To be world } \\
\text { number one PC } \\
\text { Vendor and create } \\
\text { sentiments in the } \\
\text { market } \\
\text { Lenovo's that } \\
\text { manage USA loss } \\
\text { making companies } \\
\text { better with its skills } \\
\text { of management \& } \\
\text { cost cutting }\end{array}$ & $\begin{array}{l}\text { Product range of } \\
\text { Lenovo has end } \\
\text { to end offerings } \\
\text { ranging from } \\
\text { smart phones } \\
\text { (Motorola), } \\
\text { tablets and PCs } \\
\text { to storage, } \\
\text { networking, and } \\
\text { servers. }\end{array}$ & $\begin{array}{l}\text { Singh } \\
(2015 a) \\
\text { Singh } \\
(2015 b)\end{array}$ \\
\hline
\end{tabular}

The Lenovo acquired loss making companies/units of the companies and entered in to strategic partnerships with many companies. The acquisition and 
Singh N.P.: Lenovo Acquired Motorola Mobility in a Bipolar World of Mobile phone...

strategic partnership of Lenovo includes IBM PC Business (acquisition December 2004), Lenovo Mobile Communications (November 2009), NEC PC Joint Venture (January 2011), Germany's Medion AG (July 2011), CCE Brazil PC Maker (September 2012), Stoneware (partnership -December 2012), EMC ${ }^{2} /$ lomega (December 2012), CCE Brazil (January 2013), IBM x86 Server Business (acquisition-January 2014), and Motorola Mobility (January 2014). The comparison of three main deals is given in table 1 . These acquisition and partnership indicates Lenovo had followed inorganic path strategies of growth like other large companies across the world. However, its acquisitions are not very big in terms of dollar value like Microsoft, Google, Verizon, etc.

\subsection{The Deal to Acquire Motorola}

Lenovo mission is being leader in manufacturing of smartphones like personal computer segment. It had added brand Motorola in its basket which could not be nurtured by Google. As reported by Burt (2014) Lenovo will accommodate 3,500 employees (about 2,800 are located in the United States) of Motorola. Lenovo will operate Motorola as a wholly owned subsidiary with its headquarters in Chicago, USA. Blair (2014) reported that Google had kept most of Motorola's patents and will provide Lenovo a license for the usage of patents and other intellectual property as part of the deal.To be more precise, Lenovo will get (i) brand and trademark, (ii) future product roadmap, (iii) license to intellectual property, and (iv) over 2000 patent assets out of $17500_{+}$ patents (Bloomberg (2014a)).The deal brings Motorola's portfolio of phones including the flagship Moto $X$, the Droid line, lower-end Moto $G$ and Moto $E$ to Lenovo basket (Blair (2014)). It is further reported by NDTV (2014) that Google will buy $5.94 \%$ stake (worth US $\$ 750$ Million) in Lenovo once the deal is complete. Google will hold on to the Advanced Technology and Projects group of Motorola Mobility, which involved Project Ara and other interesting ideas like tattoo security sensors and vitamin authentication pills (Krazit (2014)).

The deal was announced in January 2014 and was completed on October 30, 2014 (Howarth (2014), News (2014b)). It is the biggest ever overseas acquisition by a Chinese company in technology sector. This deal is very similar to Nokia and Microsoft deal. In case of Microsoft and Nokia, Nokia kept its patents portfolio (which it will license to Microsoft) and some assets, including the Here Maps product and part of its team. Microsoft has got manufacturing, engineering, design and development teams (Rowinski (2015)). 
Singh N.P.: Lenovo Acquired Motorola Mobility in a Bipolar World of Mobile phone...

\subsection{Why Lenovo bought Motorola Mobility?}

Lenovo bought Motorola Mobility with many objectives. Major ones, as reported by the experts are listed in the following. It may not be an exhaustive list.

Presence in Major Markets: Lenovo was not having a significant presence in the smartphone segmentin USA but Motorola had (Chawla (2014), Segan (2014)). Motorola is still a known name in the large markets of Western Europe, India, and Latin America. Lenovo believes that Motorola Mobility will provide a short cut route to make entry in mature, large, and growing markets of smartphone business which in turn may help it in becoming global leader in mobile phone segment (Hoon (2014)). Lenovo believe that with strong presence in the home country along with presence in US, Europe, India and Latin America will help him creating a brand, asset and acquiring more loss making companies across the globe or countries of its operations,

Strategic Relations: The deal will help Lenovo to have strategic relations with Android owner, Google to compete with Apple and Samsung (Dignan and Whittakar (2014)). In addition, it will help in developing business relations with telecom carriers in US since Motorola relations with US carriers were very good and Motorola was always keen to exploit these relations for expanding its market share in USA (Dignan and Whittakar (2014), Segan (2014)).

Stagnation of PC Business: Lenovo is number one PC vendor but PC market is not growing as expected in the recent quarters. Lenovo need to excel in smartphone segment of technology market which is growing currently and will continue to grow in years to come (Segan (2014)). Lenovo has experience in running US loss making technology companies and believe it will turnaround Motorola Mobility like ThinkPad business (Segan (2014)).

Full Technology Package: Lenovo wants to deliver full technology package to individuals as well as small and big enterprise customers of smartphone, ThinkPad PC, tablets, ThinkCenter products, low end servers (Segan (2014)).

Expansion portfolio: It is Lenovso's strategy to keep its place secure among top makers of smartphone or mobile phone through inorganic growth route with acquisition of Motorola Mobility. It also sends signal that Lenovo plan is to be a strong competitor to Apple, Samsung, and other Chinese makers. Dou (2015) mentioned that Lenovo expected that its $1 / 3^{\text {rd }}$ revenue will come from smartphone business after Motorola Mobility acquisition. But its statistics are not in line with this assumption. 
Singh N.P.: Lenovo Acquired Motorola Mobility in a Bipolar World of Mobile phone...

\subsection{The deal- A case for Google}

After buying Motorola Mobility, Google did many transactions with the assets of Motorola mobility. These transactions are presented in table 3. It is evident from these facts that it was not a loss making deal for Google (Singh (2015b)) and Google was trying to get rid of Motorola Mobility at the earliest. The specific comments of the industry experts are presented in the following.

Making of Better Smartphones: Nichols (2014) mentioned that Google and Motorola Mobility collaboration will accelerate innovation and choice in mobile computing. It will create new synergy. Consumers will get better phones at lower prices.

Recovering Investment in Motorola: Google sold set top box business to Arris, a cable equipment maker. Savitz (2012) reported Arris share holders do like the deal which is evident from the fact that in late trading, the stock of Arris has jumped by $\$ 2.45$ (or $16.9 \%$ ), to $\$ 16.99$ after the deal. Google shares were down by $\$ 1.61(0.2 \%)$ to $\$ 718.50$. It was reverse of synergy trap hypothesis but a good decision to Google. Moscaritolo (2012) reported that Google extended the benefit of patents as part of the deal to Arris by agreeing to license Google owned Motorola Mobility patents. It means Google is cashing on Motorola patent portfolio.Google had also sold its factories to Flextronics for US\$75 million.

Patents: Google was looking for patents of Motorola Mobility. By retaining patents as part of Lenovo deal, Google has proved it. These patents may be a big asset for Google in future. It is evident from the figures given in table 3 of future valuation of Motorola Mobility patents owned by Google. These patents might have not proved very effective, especially against Apple, Microsoft or even Nokia but in future these patents may be of very high value against competitors in settling the lawsuits (Nichols (2014)). It will also use patents as a strategic tool with buyers of all components of Motorola Mobility assets. Marriman (2014) mentioned that the deal will spare Google from litigations with Microsoft. Lenovo has a longstanding patent sharing agreement with Microsoft and litigation may be settled with not much problem.

Miss fit Acquisition \& Rightful write-off: Mims (2014) said that Motorola Mobility was an odd acquisition by Google. Industry did not supported Google view that Motorola mobility will be just like other smartphone manufacturers partners for Android. Mims (2014) also mentioned that Motorola mobility was bought to counter Samsung and Apple by Google. Knowing this fact Samsung tried to incubate its own OS Tizen. To counter this move of Samsung and fear of competition among other Android smartphone makers, Google was keen to write off the idea of being device maker and to compete with other device makers. Lawson (2014) reported that deal has taken money-losing asset off 
Singh N.P.: Lenovo Acquired Motorola Mobility in a Bipolar World of Mobile phone...

Google's books and simultaneously make its partners more comfortable by investing in Android to make it more feature rich. Mupaso (2014) mentioned that Google was struggling to command a strong position in the Smartphone business with just $1 \%$ of the market share. Google was looking to get rid of Motorola Mobility. It is evident from the data given in table 4 that Motorola Mobility was a loss making for Google and presently for Lenovo (Sikka (2014), Florin (2015)).

Making of Peace with Samsung: Singh (2015b) said that it was a win-win situation for Lenovo and Google because Lenovo feel that it can turnaround Motorola and Google is having patents with no loss making activity.Further, Krazit (2014) reported that Google has bought peace with Samsung by selling Motorola mobility to Lenovo. This is evident from the fact that Samsung will not peruse its OS plan and worked out a global license deal with Google for Android.

Table 3: Transaction of Google (Billion US\$) in the context of Motorola Mobility

\begin{tabular}{|l|l|l|l|l|}
\hline Events & Value & Year & Outflow & Source \\
\hline $\begin{array}{l}\text { Google Bought Motorola with } \\
17000+\text { patents }\end{array}$ & -12.5 & 2011 & -12.5 & Nichols (2014) \\
\hline Motorola Cash & 3.2 & 2011 & -9.3 & Nichols (2014) \\
\hline Deferred Tax Assets & 2.4 & 2011 & -6.9 & Nichols (2014) \\
\hline $\begin{array}{l}\text { Google sold Motorola set top } \\
\text { box business to cable } \\
\text { infrastructure company Arris } \\
\text { Group. }\end{array}$ & 2.35 & 2012 & -4.55 & $\begin{array}{l}\text { Savitz (2012), } \\
\text { Nichols (2014) }\end{array}$ \\
\hline $\begin{array}{l}\text { Google sold Motorola's } \\
\text { factories business to } \\
\text { Flextronics } 0.075\end{array}$ & 2013 & -4.475 & $\begin{array}{l}\text { Baptiste Su } \\
(2014)\end{array}$ \\
\hline $\begin{array}{l}\text { Motorola Mobility is sold to } \\
\text { Lenovo with 2000 patents }\end{array}$ & 2.91 & 2014 & -1.565 & Panzarino (2014) \\
\hline $\begin{array}{l}\text { Losses in operations (Quarter } \\
\text { 2 to Quarter 4), 2012 }\end{array}$ & -1.05 & 2012 & -2.615 & Mick (2014) \\
\hline $\begin{array}{l}\text { Losses in Operations (Quarter1 } \\
\text { to Quarter 3), 2013 }\end{array}$ & -0.861 & 2013 & -3.476 & Mick (2014) \\
\hline Values of Patents (Estimated) & 5.5 & 2012 & 2.024 & Panzarino (2014) \\
\hline
\end{tabular}

Source: Singh (2015b)

It can be further ascertained from the data given in table 4 that Motorola Mobility was a loss making company before it was acquired by Google. It continues to make losses under Google and still a loss making unit of Lenovo. It was in the interest of Google to sell off an odd business for it with no loss but gains as evident from the data given in Table 3 . In addition with large number of Motorola mobility patents it will have better controls over its competitors as well over Lenovo. 
Singh N.P.: Lenovo Acquired Motorola Mobility in a Bipolar World of Mobile phone... 
Singh N.P.: Lenovo Acquired Motorola Mobility in a Bipolar World of Mobile phone...

Table 4: Losses of Motorola Mobility from Q1 2010 to Q2 2015

\begin{tabular}{|c|c|c|}
\hline $\begin{array}{c}\text { Year/ } \\
\text { Quarters }\end{array}$ & Losses [L]/Profits [P] & (US\$ Billions) \\
\hline Q1 2010 & 212 [L] (Statista (2016a)) & 2.480 (Statista (2016b)) \\
\hline Q2 2010 & $80[\mathrm{P}]$ (Statista (2016a)) & 2.609 (Statista (2016b)) \\
\hline Q3 2010 & 34 [L] (Statista (2016a)) & 2.946 (Statista (2016b)) \\
\hline Q4 2010 & $\begin{array}{c}80 \text { [L] (Statista (2016a), (Epstein } \\
(2011))\end{array}$ & $\begin{array}{c}3.425 \text { (Epstein (2011)), } 3.425 \\
\text { (Statista (2016b)), }\end{array}$ \\
\hline Q1 2011 & 81 [L] (Statista (2016a)) & 3.032 (Statista (2016b)) \\
\hline Q2 2011 & $\begin{array}{c}56 \text { [L] (Statista (2016a)), } 23 \text { [OL-GAAP] } \\
\text { (Crook (2012)) }\end{array}$ & $\begin{array}{l}3.337 \text { (Statista }(2016 b)), 3.3 \\
\text { (Crook (2012)) }\end{array}$ \\
\hline Q3 2011 & $\begin{array}{c}32 \text { [L] (Statista (2016a)), } 5 \text { [OL-GAAP] } \\
\text { (Crook (2012)), 41 [OL-GAAP] } \\
(\text { Molen(2012)) }\end{array}$ & $\begin{array}{c}3.259 \text { (Statista (2016b)), } 3.3 \\
\text { [GAAP] (Crook (2012)), Molen } \\
(2011))\end{array}$ \\
\hline Q4 2011 & $\begin{array}{c}80 \text { [L] (Statista (2016a)), } 81 \text { [OL-GAAP] } \\
\text { (Crook (2012)) }\end{array}$ & $\begin{array}{l}\text { 3.436 (Statista (2016b)), } 3.4 \\
\text { [GAAP] (Crook (2012)) }\end{array}$ \\
\hline Q1 2012 & $\begin{array}{c}86 \text { [L] (Statista (2016a)), } 121 \text { [OL], } 73 \\
\text { [OL-GAAP] (Crook (2012)) }\end{array}$ & $\begin{array}{l}\text { 3.078 (Statista (2016b)), } 3.1 \\
\text { [GAAP] (Crook (2012)) }\end{array}$ \\
\hline Q2 2012 & $\begin{array}{c}49 \text { [L-Non-GAAP] (Sikka (2014)), } 233 \\
\text { [OL-GAAP] (Crook (2012)) }\end{array}$ & $\begin{array}{c}1.25 \text { (Parez (2012)), 1.3 [GAAP] } \\
(\text { Crook (2012)) }\end{array}$ \\
\hline Q3 2012 & $\begin{array}{c}192 \text { [L-Non-GAAP] (Sikka (2014)), } 527 \\
\text { [OL-GAAP] (Crook(2012)) }\end{array}$ & 2.58, 2.6 [GAAP\} (Crook (2012)) \\
\hline Q4 2012 & 152 [L-Non-GAAP] (Sikka (2014) & 1.51 (Martonik (2014)) \\
\hline Q12013 & $\begin{array}{c}182 \text { [L] (Cheng (2014)), (179 [OL- } \\
\text { NonGAAP] (Sikka (2014) or } 271 \text { [OL- } \\
\text { GAAP] (Gunther (2013)) }\end{array}$ & 1.02 (Gunther (2013) \\
\hline Q2 2013 & 218 [L- Non-GAAP] (Sikka (2014)) & 0.998 (Vikas (2014)) \\
\hline Q3 2013 & 248 [L-Non-GAAP] (Sikka (2014)) & 1.18 \\
\hline Q4 2013 & 384 [L-Non-GAAP] (Sikka (2014)) & 1.24 (Martonik (2014)) \\
\hline Q1 2014 & 198 [L] (Cheng (2014)) & 1.45 (Cheng (2014)) \\
\hline Q2 2014 & 68 [L] (Maxham (2014)) & $\begin{array}{c}1.73^{*} \text { (Vikas (2014), Maxham } \\
(2014))\end{array}$ \\
\hline Q3 2014 & $\begin{array}{c}89 \text { [L] (ET Bureau (2015), Presee } \\
\text { Release (2015a)) }\end{array}$ & $\begin{array}{c}1.90 \text { (ET Bureau (2015), Press } \\
\text { Release (2015a)) }\end{array}$ \\
\hline Q4 2014 & Loss making & 1.90 (Florin (2015)) \\
\hline Q12015 & 292 [PTL] (Press Release (2015b)) & 1.20 (Press Release (2015b)) \\
\hline Q2 2015 & 217 [PTL] (Press Release (2015c)) & 1.40 (Press Release (2015c)) \\
\hline Q2 2015 & $714[\mathrm{NL}]$ & 12.2 (Baburajan (2015)) \\
\hline
\end{tabular}

\subsection{Impact of the deal on Lenovo and its operations:}

This section presents impact of the deal on the performance of Lenovo during 2014, 2015 and 2016. In general, year 2014 has many positive side of the deal for Lenovo as reported by experts and researchers. On the other hand situation was opposite during 2015 and 2016. 
Singh N.P.: Lenovo Acquired Motorola Mobility in a Bipolar World of Mobile phone...

\section{Year of Positives}

Lenovo a Multinational Company and Global Leader: The acquisitionof Motorola Mobility and other companies had made Lenovo a true multinational company.Lenovo became third largest smartphone vendor during Q4, 2014 pushing Xiaomi from the No. 3 position down to No 4 as a result of deal as per the data given in Table 9 but later on it is taken over by the Chinese manufacturers. It has also become No 3 smartphone vendor in India but will face strong competition from local brands such as Lava, Karbonn, and Micromax in addition to international brands (Aulakh (2014)). It is evident from the data presented in table 5 to table 9 with respect to its global market share in mobile and smartphone segment.Its market share of smartphone was 6.59\% during Q3, 2014 and its financial performance was also at peak during three quarters of 2014 as per the financial summaries given in table $6 \mathrm{a}$ and table 6b. Dallke (2015) mentioned that Motorola smartphone sales of 10 million in Q3, 2014 were a record sale. It was 118\% year-to-year and added 1,9 billion in its revenue. Money (2015) reported that Lenovo's Q4 smartphone shipments grow 78 percent (24.7 Million devices) after the acquisition of Motorola mobility. Mondal (2015) reported similar gain with Motorola for Lenovo.

Complete Device player\& more presence in developed markets: Sikka (2014) reported that Lenovo is at par with Apple having product line which contain PCs, smartphones, and tablets. Lenovo can offer better products and services to enterprise customers with low maintenance cost. Acquisition of Motorola Mobility have increased the presence of Lenovo in lucrative markets specifically USA and Europe.

Downgrading of Lenovo: Lenovo is downgraded by UBS, Morgan Stanley, Jefferies Group, JI-Asia Research and Kim Eng Securities. It share fell $16.4 \%$ on the first day of trading of the year after the two deals were announced. Motorola Mobility is expected to lose money for next three fiscal years and it is likely to drag overall profitability due to acquisition of Motorola Mobility (Bloomberg News (2014b)).

New Line of Products: O'Hora (2014) said that Motorola mobility deal will make Lenovo global player. Motorola and Lenovo have a shared history of innovation. There may be new line of products in future in place of existing products of Motorola and Lenovo. Motorola and Lenovo customers may see more commonalities among two brands.

Strategic Change with respect to Emerging Markets: Dignan and Whittakar (2014)) mentioned that after acquiring Motorola mobility, Lenovo has changed its strategy which was earlier emerging market centric. Panzarino (2014) reported that acquisition of Motorola Mobility by Google had raised the profile of Motorola and it may help Lenovo in days to come. However, going 
Singh N.P.: Lenovo Acquired Motorola Mobility in a Bipolar World of Mobile phone...

by statistics of Motorola mobility given in Tables 5 to 9 , the profile of Lenovo is on decline.

Research \& Development and Android Strategy: Shah (2014) reported that Lenovo will not change policy of making pure Android smartphones and fast software upgrade strategy of Motorola.Research team of two companies will merge in to one to create more feature rich handsets under multiple brands particularly in the context of data security of customers.

Good News for Workforce: Howarth (2014) reported that deal is good news for 3500 employees and more so for 2800 employees of Motorola mobility in USA who currently design, engineer, sell, and support its current devices. Lenovo did not announced layoff plans like Microsoft in case of Nokia but may go in the same way.

New Strategies: Lenovo is known for transparency in business and had earned faith of customers of PCs and tablets. This may help Lenovo in smartphone business too. The owner of Lenovo and Motorola product will have feel of two manufacturers in days to come. Lenovo will continue to be a hardware company. Lenovo does not have app stores or a cohesive set of services \& software's customized for its mobile devices and PCs like its competitor Apple. Lenovo will not concentrate on software and services (Shah (2014)).

\section{Year of Negatives}

Cost Cutting or Reduction in Manpower: Shih (2015) reported that Lenovo will layoff 10 percent (manufacturing employees) of white-collar staff. The reason cited was fall in sales of Motorola handsets. Shih (2015) also mentioned that deal may not make Lenovo global Smartphone leader in near future. Mobile division losses are at US\$300 Million. Cutting 3200 jobs will save US\$600 million to Lenovo. Degrasse (2015) said that Lenovo plan to save US $\$ 1.35$ billion as a whole and US $\$ 850$ million from mobile unit. Even the employees who won patents for Motorola are looking for jobs.

Cipriani (2015) reported that making Motorola lean was part of Lenovo strategy to take care losses due to falling sales of PC and slowing demand of Smartphone. Bastin (2015) reported that Lenovo's mobile division recorded pre-tax loss of US\$292 million in the three months to the end of June, 2015 (Table 4). He had reported that a cost cutting strategy is in place by way of cutting 3200 jobs ( $5 \%$ of its global workforce) which will save US\$ 650 million. Elahi (2015) also reported that Motorola Mobility is retrenching 500 workers from of its Chicago workforce rather than recruiting 1000 more by the end of 2015 as pledged at the time of acquisition. It shows that Lenovo's Motorola gamble is not in line with its expectations and may result in to liability for longer duration (Gent (2015)). Linder (2015) reported that employees behind the Moto Voice, Moto Display, Moto Assist, and other software designed to 
Singh N.P.: Lenovo Acquired Motorola Mobility in a Bipolar World of Mobile phone...

bring touchless controls, subtle notifications, and other features first introduced on the original Moto $X$ will be losing their jobs..

Motorola Brand V/s IBM Brand: Bastin (2015) reported that Motorola brand is not enjoying the reputation of brand IBM. Lenovo could have declared by now that brand Motorola will be replaced with brand Lenovo

Merging of Lenovo Mobile Business Group (MBG) and Motorola Mobility: Ghoshal (2015) reported that Lenovo has started merging of MBG and Motorola Mobility. He had also mentioned that MBG will be responsible for business, but depend on Motorola to design, develop and manufacture smartphone products.

Closing of Offices: Kennemer (2015) reported that Lenovo is planning to close 3 major Motorola offices, and have a majority of the business taking place from Motorola's current labs situated in Merchandise Mart, a downtown Chicagoan business park.

Motorola will be more like Google: Savov (2015) reported that Motorola will make Android phones that Google wants user should have, Lenovo has given resources and freedom to Motorola unit to devise its strategy for growth. Motorola will reduce the dependence on carriers. It means its strategy will be similar to Google that was based on three criteria, i.e., deliver pure Android phones, spurn the carriers, and slash prices.

\section{Year is predicted}

Going by trend of 2015, Lenovo may arrest some negative impacts of 2015 but miracles are not expected during 2016. Some important trends and possible Lenovo initiatives are listed in the following.

New Product Innovations: Lenovo made an announcement that it is working with Google to develop the Tango smartphone. The device will be available in the summer of 2016. Device is equipped with Qualcomm Snapdragon processor. Project Tango's hardware requirements are an RGB camera, an infrared camera and a fish eye camera. Google's Project Tango is a technology platform that is based on advanced computer vision, depth sensing and motion tracking to create on-screen 3D experiences, allowing users to explore their physical environments via their device. Lenovo is inviting companies to help grow the Project Tango app ecosystem. The app incubator program is open to all developers, who can submit their proposals for a chance to win funding and have their app preloaded on Lenovo's upcoming smartphones. The submission period closes on 15 February 2016 (Telecompaper (2016), Tilley (2016)).

Expansion of Manufacturing Capacities: Dhapola (2015) reported that Lenovo is starting manufacturing of smartphone at Chennai (Southern State 
Singh N.P.: Lenovo Acquired Motorola Mobility in a Bipolar World of Mobile phone...

of India) factory. Flextronics is given contract to set up facility. It has capacity of making 6 million smartphones. Company will maintain separate production lines for Motorola mobility and Lenovo smartphones.

Markets Specific Strategy: Layak (2015) mentioned that Lenovo will keep Lenovo and Motorola brand separate in India like China and will increase exclusive stores. In Chinese Market, Lenovo will target all segments of smartphone market with Motorola brand (Leopold (2015)).

Layoff: Lenovo is planning to layoffless than two percent of its approximately 55,000 employees globally primarily impacting its Motorola Mobility smartphone business (Heater (2016)).

Declining Rank: Data with respect to smartphone market share for 2016 Q2 indicates that first five ranks are captured by Samsung. Apple, Huawei, OPPO, and vivo. Lenovo is included in others category. During Quarter 2, it has also observed a negative EPS as shown in Table $6 \mathrm{~b}$.

\subsection{Impact on other Stakeholders of Ecosystem:}

Competition: Perez (2014) reported that Lenovo will now compete with Samsung and Apple in the smartphones market. Lenovo will face stiff competition in home country from Chinese manufactures such as Xiaomi and Huawei in addition to Apple and Samsung. Retaining its space in higher domain of top four to five makers will be difficult task for Lenovo. In other large markets such as India, Lenovo will face fierce competition from local brand which are dependent of Chinese manufacturing facilities. But recent statistics shows it needs to compete with OPPO and vivo (http://www.idc.com/prodserv/smartphone-market-share.jsp)

Channel partners: Lenovo started process of addressing the main concerns of its channel partners ahead of two deals (x86 servers and Motorola Mobility). Haber (2014) reported that 3200 new channel partners have signed with Lenovo. Lenovo is pursuing one channel policy for its products after acquiring x 86 server businesses and Motorola mobility. Lenovo channel partnership is appreciated by majority of its partners. The Indian channel partners are highly appreciative of policies for channel partners by Lenovo ${ }^{2}$.

Role of regulatory bodies: In all merger and acquisitions, the role of regulatory bodies is very important. Google needed approval of regulators from US (Committee on Foreign Investment in the United States (CFIUS)), China. Chinese authorities put some conditions such as Google must keep its

\footnotetext{
${ }^{2}$ http://www.goapl.in/admin/inc/ckfinder/userfiles/files/Continuing\%20the\%20channel\%20lega cy_April,\%202015.pdf
} 
Singh N.P.: Lenovo Acquired Motorola Mobility in a Bipolar World of Mobile phone...

mobile software, Android, free for other device makers for up to five years as per business news of BBC (2012).

Android Ecosystem Wins: Ecosystem of Android had a major player with deep resources to challenge Samsung. Motorola can probably be revived only by Lenovo with its massive manufacturing capacity, deep pockets, solid product lines, large customer base, and long term association with channel partners all over the world. Its revival will be a big win for Android ecosystem.

\section{Analysis of Data \& Interpretation with respect to research questions}

Based on the analysis of data in the form of event analysis, content analysis, and trend analysis presented in earlier sections, the possible answers to 10 research questions are summarized in the following.

Research Question 1: Will Lenovo repeat success of IBM's previous ThinkPad business deal in case of Motorola Mobility?

Carsten (2014) said that cost cutting lessons learned in case of Think Pad Business will help Lenovo to convert loss making Motorola Mobility in to profit making business. In short term deal may have negative impact of the performance of Lenovo. According to Lenovo sources, it may take three to five quarters to turnaround Motorola Mobility business. Singh (2014) reported that Lenovo will face many hurdles in achieving the success. In recent years, Motorola market share fallen amid stiff competition. None of the Motorola product had created a buzz in the market. There is huge gap between Lenovo and market leader Apple \& Samsung. Young (2015) mentioned that Lenovo is first major loser in the ongoing war for market share among Chinese big smartphone makers. He also said that Lenovo should write off Motorola investment. Based on these facts it can be inferred that it will not be possible in near future to become leader in smartphone segment. Ngo (2017) reported similar sentiments and mentioned that "Lenovo's smartphone business, for example, has been costing the company more than 100 million USD every quarter".

Research Question 2: Is Synergy Trap Hypothesis true in acquisition of Motorola Mobility Business?

As per synergy trap hypothesis immediately before and afteran acquisition announcement, the acquiring firm's stock price is negatively affected and the target firm's stock price is positively affected (Myeong-Cheol, et al (2002)). The deal was announced in January 2014 and as reported by Phys.org (2014), Lenovo's shares at Hong Kong exchange have slumped around 14\%. Lenovo stock prices were negatively affected but not much change was 
Singh N.P.: Lenovo Acquired Motorola Mobility in a Bipolar World of Mobile phone...

observed by Motorola stock. It means that to some extent the synergy trap hypotheses is true. The stock prices have fallen at Hong Kong exchange in the month of November, 2014 a period after the deal.

Research Question 3: Will it help Lenovo to acquire more loss making units if any and do innovation in smartphone manufacturing technology and processes?

In an environment of fierce competition of making smartphones with rich features at competitive pricesand with little or no differentiation in terms of operating system, many more global or regional smartphone makers may become candidates for acquisition by big companies such as Lenovo. Going with statistics as given in table 5 to 9 , it looks impossible in near future that Lenovo will go for additional takeover and reviving of loss making units.

Research Question 4: Will it diversify or expand Lenovo markets for its existing products as well as products of acquired Motorola Mobility?

Bloomberg News (2015) mentioned that after the acquisition of Motorola mobility, Lenovo's business will be more geographically diversified. Lenovo will have bigger basket of products. Lenovo is now less dependent on the China market and PC products. According to Osawa (2014) smartphone will be a new source of growth for Lenovo and compensate for saturation of PC segment. But going by data of last three year performance, Lenovo will have to wait for longer duration to convert Motorola mobility investment in to profit.

Research Question 5: Is inorganic expansion path better for faster growth in high tech electronic industry such as smartphones?

Yes, it enhancesgrowth in high tech electronic industry. In case of Motorola Mobility, Lenovo will be benefitted by (i) having footprints ofits brands (Lenovo+ Motorola) in North America and other mature markets, (ii) leveraging Motorola Mobility's strong relations with telecommunication carriers in USA, (iii) having hold of some intellectual properties of Motorola, (iv) enhancing the customer base with the customers of acquired Motorola Mobility, (v) having control of new projects of Google, (vi) research and development team of Motorola, and (vii) possible favors from Google due to attitude of Samsung towards Android. This fits with the Lenovo's inorganicstrategy of expansion as evident from the data presented in Table 1.In the recent past, Lenovo is looking for even acquiring local BPO companies (Pinaroc (2014)). This is another example that inorganic growth is more on the future agenda of Lenovo in comparison to organic growth.

Research Question 6: Will Lenovo retain the brand Motorola in the long run along with brand Lenovo? 
Singh N.P.: Lenovo Acquired Motorola Mobility in a Bipolar World of Mobile phone...

It is reported at many forums by Lenovo that it will retain both brands, i.e., Motorola and Lenovo. Motorola brand will be marketed in USA, Latin America and Europe and Lenovo brand in China and emerging markets. Further to it, Lenovo is planning to introduce Motorola brand in China (Kelion (2014)). Microsoft made a similar statement that it will retain brand Nokia after its purchase of that failing manufacturer. It has recently announced that all new Lumia devices will carry the Microsoft brand rather than Nokia (Howarth (2014)). In India both Lenovo and Motorola will compete in the same segments. Lenovo also announced that its manufacturing units in India will maintain separate lines of manufacturing for Lenovo and Motorola but in the long run Lenovo may not retain Motorola brand.

Research Question 7: Will huge local market for smartphones help Lenovo to repeat the success of ThinkPad PC business acquisition?

Reuters (2015) reported that Motorola mobility has no share in big market of China. Motorola hope to capture some segment of this market from strong competitors such as Apple and Samsung in the premium smartphone segment and from local makers (Xiaomi and Huawei) in mid and mid-high segment of smartphone segment. Lenovo is already the number two smartphone maker in China. Motorola reported that its approach will have global products tailored and customized for local markets. Motorola may even try to sell smartphone manufactured for USA market. Lenovo is financially strong and have good number of channel partners but it will be very difficult for Lenovo to compete with Apple, Samsung and local makers of smartphone in many segments of the local market. Local market size is in favor of Lenovo but in view of shrinking PC market and competition on many fronts, it will be difficult for Lenovo to gain markets in China with loss making brand Motorola. Ngo (2017) reported that Lenovo market share in home market reduced to $2 \%$ from $12 \%$ earlier.

Research Question 8: Will Lenovo be a test case for cash rich Chinese Companies?

It is reported by experts that cash rich Chinese companies are looking for opportunities of expansion in overseas markets by acquiring loss making companies or the companies which are aligned with their strategic goals. Lenovo success of ThinkPad business encouraged Lenovo to again acquire x86 Servers business and Motorola mobility. If these two deals become successful in two to three years, other Chinese companies will look for similar strategy of growth and making entry in to new markets. In fact Chinese companies are engaged in mergers and acquisition in entertainment, agriculture, real estate, energy, and automobiles

Research Question/Proposition 9: Will layoff employees lead to down fall of the Lenovo in near future? 
Singh N.P.: Lenovo Acquired Motorola Mobility in a Bipolar World of Mobile phone...

Though it is not very unique to Lenovo but still retrenching the manpower of key functional units have created negative environment on the image of Motorola brand in America and in other markets. Unless the trend is changed, Motorola unit will never be turned around and will slowly exit from the smartphone market. Google bought Motorola mobility with over 20,000 employees but by Q4, 2103 these numbers reduced to 3894 (Jeff (2014)). According to Collins (2010) layoff impacts stock prices, decreases profits, doesn't boost productivity, does not cut cost, tarnishes the brand, and a symbol of bad decisions of management. It has impacted Lenovo negatively. Ngo (2017) reported that Lenovo had accepted that it had underestimated the cultural and structural differences between Lenovo and the American-based Motorola Company.

Research Question/ Proposition 10: Lenovo acquired Motorola Mobility for strategic tie up with Google and US major telecom carriers.

Perez (2014) reported that it is strategic tie up. It is much more than getting market share. Google will hold shares worth US $\$ 750$ million and expected to share its wisdom with Lenovo in the domain of smartphones business. Marriman (2014) reported ties forged between Google, Samsung and Sony. These ties are in the context of patent sharing agreements. Google has power of mobile patents, but free of the manufacturing. It means smartphone makers need to realize that cooperating with Google is right thing to do. Lenovo understand it and forged a strategic tie with Google. Its tieing with telecom majors had not increased its market share in North America.

\section{Conclusions}

Based on the good sales of Motorola Mobility phones in last two quarters (Q3,Q4), 2014, it was reported by Lenovo that it will take 6 quarters for Motorola Mobility to become profitable. But this upward trend of sales of Motorola Mobility smartphone was short lived as can be seen from the data given in table 5 to 9 . Given these facts, it will be very difficult for Lenovo to revive Motorola Mobility in near future or to become a global or home market leader in smartphone segments. First of all Lenovo needs to become leader among his home country mobile phone as well as smartphone makers. In global mobile market, it is lagging behind Huawei and at par with another mobile phone Chinese maker Xiaomi as evident from the data given in table 7. Share of Huawei during Q3, 2015 was $5.7 \%$ in comparison to $3.7 \%$ of Lenovo + Motorola. Share of Huawei had increased from 3.8\% during Q4, 2014 to $5.7 \%$ during Q3, 2015. On the other hand share of Lenovo + Motorola had declined from 4.5\% during Q4, 2014 to 3.7\% during Q3, 2015. Status of smartphone segment is the same. The data of smartphone market share in 
Singh N.P.: Lenovo Acquired Motorola Mobility in a Bipolar World of Mobile phone...

world is given in table 8 and table 9 . It can be seen from the data that Lenovo share during Q3, 2015 was $4.9 \%$ in comparison to $7.7 \%$ of Huawei and $4.9 \%$ of Xiaomi. Numbers of units shipped by Lenovo are much less than Huawei during 2Q, 2015. However, Lenovo shipped more number of units in comparison to Huawei during Q1, 2015 as per the data given in table 9. The trends are similar to data given in table $7 \& 8$ but there is a difference between figures of percentage as well as number in many cases. If one compare Lenovo share with leader Samsung, the difference is more than 4 times. These data sets and recent forecasts of its possible falling share in home market in the first quarter 2017 and last quarter of 2016, suggest that it may not be possible for Lenovo to compete with Samsung, Apple, and Huawei. In all possibilities it may arrest decline in sales of Motorola + Lenovo smartphones be at fifth or lower place.

Lenovo is a test case for Chinese companies in acquiring foreign companies and run these companies successfully. Success or failure (which is more likely) of Lenovo will have huge impact on Chinese companies which are keen to follow inorganic path of growth in near future in smartphone segment.

One possible scenario could be that Lenovo may take more time than it took to revive ThinkPad business. However, becoming a leader in smartphone market in near future seems impossible. Certainly, Lenovo is now more geographically diversified. Lenovo is now true multinational company. Its product basket is quite big to target enterprise customers. It has strength now to target both developed and emerging markets. Lenovo believes in inorganic path of growth but it will be difficult for Lenovo to acquire any big company in near future. If the smartphone business is not getting converted into profitability, Lenovo may dump brand Motorola. Lenovo has started integration process of Motorola Mobility and its Mobile Business Group (MBG) as reported by Singh (2015). Still more needs to be done even at the level of brand.

Laying-off personnel had created negative environment for Lenovo. Lenovo needs to expand rather than shrink by reducing manpower. Lenovo bought Motorola Mobility to have strategic tie up with Google in the context of Android. This is working successfully.

Lenovo needs to compete on price, quality and identify loss making segment of smartphone business for corrective strategies. What is needed? Lenovo should follow incremental innovation in product category as suggested by Banbury and Mitchel (1995) rather than following discrete strategy of making fundamental changes in products and processes. Not many products of Lenovo have created a big hype in the market and not all going to create a huge market in near future. The best strategy could be to get associated with its innovation partners in developing new products in smartphone segment 
Singh N.P.: Lenovo Acquired Motorola Mobility in a Bipolar World of Mobile phone...

which may become a big hit. These associates may be small technology innovators and young researchers in the domain of mobile device technology. Lenovo need to fund them initially to harvest the benefit of their intellectual capital and getting rid of internal innovation staganation if any.

\section{References}

Aulakh, G. (2014). Lenovo becomes third largest smart phone maker In India after Motorola acquisition, October 31. Retrieved on October 27, 2015 from http://articles.economictimes.indiatimes.com/2014-1031/news/55631758 1 motorola-lenovo-liu-jun-lenovo-motorola

Baburajan, K. (2015). Lenovo makes $\$ 714$ million loss on $\$ 12.2 b n$ revenue in Q2, November 12. Retrieved on November 18, 2015 from http://www.telecomlead.com/telecom-statistics/lenovo-india-achieves-48-pointsgrowth-in-mobile-shipments-in-q2-65465

Banbury, M.C. and Mitchel, W. (1995). The effect of introducing important incremental innovations on market share and business survival, Strategic Management Journal, 16, 161-182.

Baptiste Su, J. (2014). Google profits billions with Motorola sale to Lenovo, keeps patents, January 09. Retrieved on October 23, 2015 from http://www.forbes.com/sites/jeanbaptiste/2014/01/29/google-profits-billions-withmotorola-sale-to-lenovo-keeps-patents/

Barinka, A. (2014). Lenovo to buy IBM Server Unit for \$2.3 Billion amid slump, January 14. Retrieved on July 31, 2014 from http://www.bloomberg.com/news/2014-0123/lenovo-to-buy-ibm-server-unit-for-2-3-billion-amid-pc-slump.html

Bastin, M. (2015). Motorola acquisition proves to be a drag on PC giant Lenovo, September 29. Retrieved on October 25, 2015 from http://www.chinapost.com.tw/business/companyfocus/2015/09/29/447004/motorola-acquisition.htm

BBC (2012). Google completes purchase of Motorola Mobility, May 22. Retrieved on April 17, 2015 from http://www.bbc.com/news/business-18164190.

Blair, N. (2014). Lenovo wraps up Its deal to buy Motorola from Google, October 30. $\begin{array}{llll}\text { Retrieved On } 27, & 2015 & \text { From }\end{array}$ http://www.usatoday.com/story/tech/2014/10/30/lenovo-closes-motorolaacquisition $/ 18172497 /$

Bloomberg News (2014a). What does Lenovo gain from Motorola Mobility deal? (Video), January 30. Retrieved on October 27, 2015 from Http:/Www.Bloomberg.Com/News/Videos/B/6945b229-C500-47dc-A926190ef0f6616d

Bloomberg News (2014b). Lenovo punished by downgrades over Motorola Mobility acquisition deal, February, 05. Retrieved on March 01, 2015 from http://www.scmp.com/business/companies/article/1420964/lenovo-punisheddowngrades-over-motorola-mobility-acquisition

Bloomberg News (2015). Lenovo surges after profits beats estimates on smartphone's, February 03. Retrieved on October 27, 2015 from 
Singh N.P.: Lenovo Acquired Motorola Mobility in a Bipolar World of Mobile phone...

http://www.bloomberg.com/news/articles/2015-02-03/lenovo-profit-beatsestimates-on-smartphone-market-share-gains

Burns, M. (2014).Lenovo to buy Motorola Mobility from Google for $\$ 2.91$ billion, January 29. Retrieved on December 10, 2015 from Http://Techcrunch.Com/2014/01/29/Lenovo-To-Buy-Motorola-Mobility-FromGoogle/

Burt, J. (2014). Lenovo closes $\$ 2.91$ billion deal for Motorola, October 30. Retrieved on October 25, 2015 From Http://Www.Eweek.Com/Mobile/Lenovo-Closes-2.91Billion-Deal-For-Motorola.Html

Carsten, P. (2014). For Lenovo, Thinkpad turnaround provides blueprint for Motorola handset future, February, 13. Retrieved on August 12, 2014 from http://www.reuters.com/article/2014/02/13/us-lenovo-q3-resultsidusbrea1c01r20140213.

Chawla, M. (2014). Why did Lenovo buy Motorola and not HTC?, January 31.

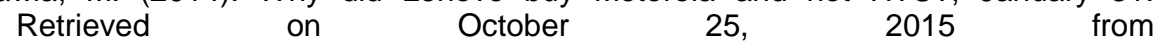
http://economictimes.indiatimes.com/news/international/ business/why-did-lenovobuy-motorola-and-not-htc/articleshow/29663984.cms

Cheng, R. (2014). Motorola losses widen ahead of sale to Lenovo, April 16. Retrieved on January 15, 2016 from http://www.cnet.com/news/motorola-losses-widenahead-of-sale-to-lenovo/

Crook, J. (2012). Motorola 3Q 2012 revenue $\$ 2.58$ billion; $18 \%$ of revenue for Google's total Q3, October 18. Retrieved on November 20, 2015 from http://techcrunch.com/2012/10/18/motorola-3q2012-revenues-2-58-billion-18-ofrevenue-for-googles-total-q3/

Cipriani, J. (2015). Can Motorola save Lenovo from Itself?, August 14. Retrieved on October 25, 2015 from http://fortune.com/2015/08/14/can-motorola-save-lenovofrom-itself/

Collins, M. (2010). Are Layoffs Bad For Business? October 22. Retrieved on December 22, 2015 from http://www.tvnewscheck.com/article/46411/are-layoffsbad-for-business.

Dallke, J. (2015). Motorola Sells A Record Number Of Smart Phones In Big Quarter Following Lenovo Deal, March 02. Retrieved On October 25, 2015 from http://chicagoinno.streetwise.co/2015/02/03/lenovo-earnings-motorola-sellsrecord-number-of-smartphones/

Degrasse, M. (2015). Motorola Mobility targeted for Lenovo layoffs, August 13. Retrieved on October 25, 2015 from http://www.rcrwireless.com/20150813/workforce/jobs/motorola-mobility-targetedfor-lenovo-layoffs-tag 4

Dhapola, S. (2015). Lenovo Motorola start smartphone manufacturing In India with Moto E, August 19. Retrieved on October 25, 2015 from http://indianexpress.com/article/technology/mobile-tabs/lenovo-motorola-startsmartphone-manufacturing-in-india-with-moto-e/

Dignan, L. And Whittakar, Z. (2014).Lenovo buys Google's handset business for \$2.91b, January 29, Retrieved on December 28, 2015 from http://www.zdnet.com/article/lenovo-buys-googles-handset-business-for-2-91b/

Dou, E. (2015). Lenovo expects Motorola to lift smart phone revenue, February 02. Retrieved on October 25, 2015 from www.wsj.com/articles/lenovo-quarterly-profitfalls-on-motorola-acquisition-1422924787 
Singh N.P.: Lenovo Acquired Motorola Mobility in a Bipolar World of Mobile phone...

Elahi, A. (2015). Motorola Mobility to cut 500 jobs In Chicago; layoff underway, August 13. Retrieved On October 25, 2015 from www.chicagotribune.com/bluesky/originals/ct-motorola-mobility-layoffs-bsi-0813story.html

Epstein, Z. (2011). Motorola Mobility reports Q4, full year earnings; Q1 2011 guidance bleak, January 26. Retrieved on November 20, 2015 from http://bgr.com/2011/01/26/motorola-mobility-reports-q4-full-year-earnings-q12011-guidance-bleak/

ET Bureau (2015). Motorola sells over 10 million smartphones in Q3, February 3. Retrieved on January $15, \quad 2016$ from http://articles.economictimes.indiatimes.com/2015-02-03/news/58751794 1 motorola-mobility-global-smartphone-market-motorola-india

Fishman, T.C. (2014). What happened to Motorola, August 25. Retrieved On October 25, 2015 from http://www.chicagomag.com/chicago-magazine/september2014/what-happened-to-motorola/

Florin, T. (2015). Over 10 million Motorola smartphones were sold in Q\$2014, February 02. Retrieved on November 18, 2015 from http://www.phonearena.com/news/Over-10-million-Motorola-smartphones-weresold-in-Q4-2014 id65506

Gent, E. (2015). Lenovo layoffs suggest Motorola gamble hasn't paid off, August 13. Retrieved on October 25, 2015 from http://eandt.theiet.org/news/2015/aug/lenovomotorola.cfm

Ghoshal, A. (2015). Motorola will now design and build, August 27. Retrieved on October 25, 2015 from http://thenextweb.com/mobile/2015/08/27/motorola-willnow-design-and-build-lenovo-phones/

Goldman, D. (2012). Google seals $\$ 13$ billion Motorola buy, May 22. Retrieved on August 30, 2015 from http://money.cnn.com/2012/05/22/technology/googlemotorola/

Gunther, C. (2013). Motorola Q1 2013 operating loss tops \$271 million, April 18. Retrieved on November 20, 2015 from www.androidcommunity.com/motorola-q12013-operating-loss-tops-271-million-20130418/

Haber, L. (2014). At Lenovo partner conference, company preps partners for IBM, Motorola buys, May 13. Retrieved on August 08, 2013 from http://searchitchannel.techtarget.com/news/2240220624/at-lenovo-partnerconference-company-preps-partners-for-ibm-motorola-buys

Heater, B. (2016).Lenovo undergoes another big layoff round, mostly impacting Motorola, September 26. Retrieved on October 08, 2016 from https://techcrunch.com/2016/09/26/lenovo-layoffs/

Hoon, K.K. (2014). Lenovo buys Motorola becoming world's third largest smart phone producer, October 30. Retrieved on October 25, 2015 from https://www.rt.com/business/200875-lenovo-buys-motorola-mobile/

Howarth, T. (2014). News: Lenovo completes acquisition of Motorola Mobility from Google, October 31. Retrieved on October 25, 2015 from https://www.virtualizationpractice.com/news-lenovo-completes-acquisitionmotorola-mobility-google-29509/

Jeff, C. (2014). Motorola Q4 2013 results: $\$ 1.24$ billion revenue, $\$ 384$ million loss, January 31. Retrieved on November 20, 2015 from http://unleashthephones.com/2014/01/31/motorola-q4-2013-results-1-24-billionrevenue-384-million-loss/ 
Singh N.P.: Lenovo Acquired Motorola Mobility in a Bipolar World of Mobile phone...

Kelion, L. (2014). Lenovo complete Motorola takeover after Google sale, October 30. Retrieved on October 25, 2015 from http://www.bbc.com/news/technology29833131

Kennemer, Q. (2015). Motorola Is Cutting 20\% Of Their Jobs And Getting A Whole New Identity Under Lenovo, August 14. Retrieved On October 25, 2015 from http://phandroid.com/2015/08/14/motorola-cuts-2015/

Krazit, T. (2014).With Motorola sale and Samsung peace, Google finds practical exit to an unconventional (and expensive) deal, January 29. Retrieved on January 17, 2016 from http://gigaom.com/2014/01/29/with-motorola-sale-and-samsung-peacegoogle-finds-practical-exit-to-an-unconvential-and-expensive-deal/

Lawson, S. (2014). With Motorola sale to Lenovo, Google is unloading a headache, January 29. Retrieved on October 27, 2015 from http://www.pcworld.com/article/2092880/with-motorola-sale-to-lenovo-google-isunloading-a-headache.html

Layak, S. (2015). How will Lenovo handle the Motorola phones brand in India?, April 26. Retrieved on October 25, 2015 from www.economictimes.indiatimes.com/magazines/panache/how-will-lenovo-handlethe-motorola-phones-brand-in-india/articleshow/47053819.cms

Leopold, G. (2015). Lenovo looks to duplicate PC success In server, smartphone markets, February 09. Retrieved on March 21, 2015 from http://electronics360.globalspec.com/article/4988/lenovo-looks-to-duplicate-pcsuccess-in-server-smartphone-markets.

Linder, B. (2015). Lenovo Cuts Jobs At Motorola, Eliminates Team Responsibility For Moto Voice, Moto Display, August 16. Retrieved On October 25, 2015 from http://iliputing.com/2015/08/lenovo-cuts-jobs-at-motorola-eliminates-teamresponsible-for-moto-voice-moto-display.html

Marriman, C. (2014). Everyone's a winner from Google's sale of Motorola to Lenovo, January 31. Retrieved on December 25, 2015 from http://www.theinquirer.net/inquirer/feature/ 2326145/everyones-a-winner-fromgoogles-sale-of-motorola-to-lenovo

Martonik, A. (2014). Motorola's final quarter under Google: $\$ 1.24$ billion revenue, $\$ 384$ million operating loss, Jnauary 30. Retrieved on September 2016 from http://iphoneeinstein.com/2014/01/motorolas-final-quarter-under-google-1-24billion-revenue-384-million-operating-loss/

Maxham, A. (2014). Google announces Q2 2014 financial earnings - \$15.96 billion in revenue, July 17. Retrieved on January 16, 2016 from http://www.androidheadlines.com/2014/07/google-announces-q2-2014-financialearnings-15-96-billion-revenue.html

Mick, J. (2014).Google to sell Motorola to Lenovo for $\$ 2.91 b$, takes $\$ 7 b+$ Net Loss, January 29. Retrieved on October 31, 2015 from http://www.dailytech.com/google+to+sell+motorola+to+lenovo+for+291b+takes+7 b+net+loss/article34231.htm

Mims, C. (2014). Why Google just sold Motorola to Lenovo for \$3 billion, January 29. Retrieved on October 27, 2015 from http://qz.com/172207/why-google-just-soldmotorola-to-lenovo-for-3-billion/

Molen, B. (2011). Motorola mobility reports $\$ 3.3$ billion in revenue and $\$ 32$ million net loss, offer more details on Google buyout, October 27. Retrieved on January 16, 2016 from http://www.engadget.com/2011/10/27/motorola-mobility-reports-3-3billion-in-revenue-and-32-millio/ 
Singh N.P.: Lenovo Acquired Motorola Mobility in a Bipolar World of Mobile phone...

Money, D. J. (2015). Lenovo's Q4 Smart phone shipments grow 78 percent after Motorola acquisition, February 03. Retrieved On October 27, 2015 from http://technews.co/2015/02/03/lenovos-q4-smartphone-shipments-grow-78percent-after-motorola-acquisition/

Moscaritolo A. (2012). Google sells Motorola's set-top box business for $\$ 2$ billion, December 20. Retrieved On October 21, 2015 from http://in.pcmag.com/tv-hometheaters/78473/news/google-sells-motorolas-set-top-box-business-for- 2 .

Mondal, P. (2016). Lenovo lay off hundreds of employees, impacts Motorola significantly, September 29. Retreived on January 31, 2017 from http://www.newseveryday.com/articles/48187/20160929/lenovo-lays-off-hundredsof-employees-impacts-motorola-significantly.htm

Mupaso, T. (2014).Global tech news roundup: Lenovo buys Motorola, January 31. Retrieved on September 30, 2015 from http://www.techzim.co.zw/2014/01/globaltech-news-roundup-lenovo-buys-motorola-hackers-hit-yahoo-wechat-aggressiveglobal-drive/

Myeong-Cheol, P., Dong-hoon,Y.Changi, N. and Young-Wook, H. (2002). Mergers and acquisitions in the telecommunications industry: Myths and Reality, ETRI Journal v24, n.1, p.56-64.

NDTV (2014).Google to buy 5.94 percent stake in Lenovo after Motorola Mobility deal, February $07 . \quad$ Retrieved on October 27, 2015 from http://gadgets.ndtv.com/mobiles/news/google-bought-594-percent-stake-inlenovo-in-motorola-mobility-deal-480428

News (2014b). Lenovo Completes Acquisition Of Motorola Mobility From Google, October 30. Retrieved on February 01, 2015 from Http://News.Lenovo.Com/Article_Display.Cfm? Article_ld $=1860$

Ngo, A. (2017). Lenovo still struggling with its three year old Motorola acquisition. January 21. Retrieved on March 10, 2017 from http://www.notebookcheck.net/Lenovo-still-struggling-with-its-three-year-oldMotorola-acquisition.192174.0.html

Nichols, S.J.V. (2014). Lenovo-Motorola Deal: For Google, It's Still All About The Patents, January 29. Retrieved on October 27, 2015 from http://www.zdnet.com/article/lenovo-motorola-deal-for-google-its-still-all-about-thepatents/

Osawa, J. (2014). Lenovo complete Motorola acquisition, October 30. Retrieved on October 25, 2015 from http://www.wsj.com/articles/lenovo-completes-motorolaacquisition-1414665138

Panzarino, M. (2014). Google keeps 'Vast Majority' of Motorola Mobility patents in sale to Lenovo, January 29. Retrieved on November 11, 2015 from http://techcrunch.com/2014/01/29/google-keeps-vast-majority-of-motorolamobility-patents-in-sale-to-lenovo/

Parez, S. (2012). Google beats In Q2 2012: Revenue up 35 per cent to $\$ 12.21 \mathrm{~b}$, $\$ 2.79 \mathrm{~b}$ in net income, July 19. Retrieved on January 16, 2016 from www.techcrunch.com/2012/07/19/google-beats-in-q2-2012-revenue-up-35percent-to-12-21b-2-79b-in-net-income/

Perez, B. (2014). Co-Operation with Google key for Lenovo's Motorola deal, February 08. Retrieved on August 29, 2015 from http://www.scmp.com/business/companies/ article/1423466/co-operation-googlekey-lenovos-motorola-deal. 
Singh N.P.: Lenovo Acquired Motorola Mobility in a Bipolar World of Mobile phone...

Phys.Org (2015a). China's Lenovo aims for third In global smartphone market, February 13. Retrieved on October 25, 2015 from http://phys.org/news/2014-02china-lenovo-aims-global-smartphone.html

Pinaroc, J. (2014). With IBM x86 acquisition done, Lenovo plans to go after BPO firms, December 08. Retrieved on January, 23, 2015 from http://newsbytes.ph/2014/12/08/with-ibm-x86-acquisition-done-lenovo-plans-to-goafter-bpo-firms/

Press Release (2015a). Lenovo Q3 2014/15 results exceed consensus estimates with strong core business and fast traction in new investments, February 3 . Retrieved on January 16, 2016 from

https://www.lenovo.com/ww/lenovo/pdf/Lenovo\%20Q3\%20FY14-15\%20OctDec\%20Earnings\%20Press\%20Release Eng\%20(final).pdf

Press Release $(2015 \mathrm{~b})$. Lenovo $1^{\text {st }}$ quarter FY 15-16: Tough market, solid results, August 13. Retrieved on January 15, 2016 from http://www.lenovo.com/ww/lenovo/pdf/Lenovo\%20FY\%202015-16\%20AprilJune\%20Q1\%20earnings\%20press\%20release English\%20(final).pdf

Press Release (2015c). Lenovo deliver solid $2^{\text {nd }}$ quarter FY 15-16 operational results, November 12. Retreived on September 2016 from https://www.lenovo.com/.../lenovo/pdf/lenovo\%20fy\%202015-16\%20julysept\%20...

Reuters (2015). Lenovo's Motorola looks to take market share from China rivals, January 27. Retrieved on October 27, 2015 from http://gadgets.ndtv.com/mobiles/news/lenovos-motorola-looks-to-take-marketshare-from-china-rivals-654097

Rosoff, M. (2015). Lenovo Is Doing A Lot Better With Motorola Than Google Did, February 03. Retrieved On October 27, 2015 from http://www.businessinsider.in/lenovo-is-doing-a-lot-better-with-motorola-thangoogle-did/articleshow/46103949.cms

Rowinski,D. (2014). Google wins by dumping Motorola on Lenovo - and so does Samsung, January 30. Retrieved on October 27, 2015 from http://readwrite.com/2014/01/29/google-motorola-lenovo-samsung-android

Savov, V. (2015). Under Lenovo, Motorola is more like Google than It ever was, July 29. Retrieved on October 25, 2015 from http://www.theverge.com/2015/7/29/9067665/ motorola-google-lenovo-pureandroid.

Savitz, E. (2012). Google to sell Motorola set-top box unit Toarris for \$2.35b, December 19. Retrieved on October 31, 2015 from http://www.forbes.com/sites/ericsavitz/2012/12/19/google-to-sell-motorola-set-topbox-unit-to-arris-for-2-35b/

Segan, S. (2014). 5 reasons why Google sold Motorola, and 5 reasons why Lenovo Bought It, January 30. Retrieved on October 25, 2015 from http://in.pcmag.com/smartphones/66822/news/5-reasons-why-google-soldmotorola-and-5-reasons-w

Shah, A. (2014). What you should know about Lenovo's Motorola acquisition, October 30. Retrieved on October 25, 2015 from www.computerworld.com/article/2841492/what-you-should-know-about-lenovosmotorola-acquisition.html

Shih, G. (2015). lenovo faces motorola hangover, cuts 3,200 jobs as sales slide, profit tumbles, august 13. Retrieved on september 01, 2015 from 
Singh N.P.: Lenovo Acquired Motorola Mobility in a Bipolar World of Mobile phone...

http://in.reuters.com/article/2015/08/13/lenovo-resultsidinkcn0qi00h20150813?type= companynews

Sikka, P. (2014). Must-Know: Why did Google sell Its Motorola business to Lenovo?, March 11. Retrieved on October 27, 2015 from http://marketrealist.com/2014/03/must-know-google-sell-motorola-businesslenovo/

Singh, M. (2015). Lenovo begins merging mobile business group into Motorola Mobility, August 26. Retrieved on October 25, 2015 form http://gadgets.ndtv.com/internet/news/lenovo-mobile-to-reportedly-be-mergedinto-motorola-mobility-732670

Singh, N.P. (2014a). Microsoft acquired Nokia In Uni-polar operating system market, Independent Journal of Management \& Production, 5(3): 598-622.

Singh, N.P. (2014b). Verizon Acquired Vodafone- Analysis of Market Reaction, Industrija (Journal Of Sustainable Economics), 42 (3): 163-182.

Singh, N.P. (2015a). Lenovo Acquires IBM's x86 Low-end Server Business, Industrija (Journal of Sustainable Economics), 43 (3): 191-219.

Singh, N.P. (2015b). Google bought and sold Motorola Mobility-What it means? International Journal of Business Policy and Strategy Management, 1: 13-24

Singh, P.P. (2014). Can Lenovo do an IBM with Motorola? January 30. Retrieved On October 27, 2015 from http://www.bbc.com/news/business-25956864

Spooner, J.G. and Kanellos, M. (2014). IBM sells PC group to Lenovo, December 07. Retrieved on August 08, 2014 from http://news.cnet.com/ibm-sells-pc-group-tolenovo/2100-1042 3-5482284.html

Statista (2016a). Profit/loss of Motorola mobility worldwide from $1^{\text {st }}$ quarter 2010 to $1^{\text {st }}$ quarter 2012 (in million U.S. dollars). Retrieved on January 15, 2016 from http://www.statista.com/statistics/274221/profit-and-loss-of-motorola-mobilityworldwide/

Statista (2016b). Global net revenue of Motorola from $1^{\text {st }}$ quarter 2010 to $1^{\text {st }}$ quarter 2012 (in million U.S. dollars). Retrieved on January 16, 2016 from http://www.statista.com/statistics/274220/global-net-revenue-of-motorola-mobilitysince-2010-by-quarter/

Telecompaper (2016).Lenovo developing first Google project Tango smartphone, January 08. Retrieved on January 09, 2016 from http://www.telecompaper.com/news/lenovo-developing-first-google-projecttangosmartphone--1121964

Tilley, A. (2016). Lenovo will launch a 3D mapping phone with Google, January 08. Retrieved on January $10, \quad 2016$ from http://www.forbes.com/sites/aarontilley/2016/01/08/lenovo-google-project-tangophone/

Vikas, S.N. (2014). Google revenues at $\$ 16 \mathrm{Bn}$ for Q2 2014; paid click up 25\% while CPC dips 6\%, July 18. Retrieved on January 16, 2016 from http://www.medianama.com/2014/07/223-google-q2-2014-earnings/

Young, D. (2015). Lenovo overhauls mobile unit around Motorola, August 28. Retrieved on October 25, 2015 from http://www.forbes.com/sites/dougyoung/2015/08/28/lenovo-overhauls-mobile-unitaround-motorola/ 
Singh N.P.: Lenovo Acquired Motorola Mobility in a Bipolar World of Mobile phone...

\section{Appendix}

Table 5: Yearly Global Market Share by Units (\%) of Major Manufacturers (2009-2015)

\begin{tabular}{|c|c|c|c|c|c|c|c|}
\hline Vendors & $\begin{array}{c}2009 \\
{[1]}\end{array}$ & $\begin{array}{c}2010 \\
{[2]}\end{array}$ & $\begin{array}{c}2011 \\
{[3]}\end{array}$ & $\begin{array}{c}2012 \\
{[3]}\end{array}$ & $\begin{array}{c}2013 \\
{[4]}\end{array}$ & $\begin{array}{c}2014 \\
{[5]}\end{array}$ & $\begin{array}{c}2015 \\
\text { Q2 } \\
{[6]}\end{array}$ \\
\hline Samsung & 19.5 & 17.6 & 17.7 & 22.0 & 24.6 & 20.9 & 19.9 \\
\hline Nokia & 36.4 & 28.9 & 23.8 & 19.1 & 13.9 & - & - \\
\hline Apple & 2.1 & 2.9 & 5.0 & 7.5 & 8.3 & 10.2 & 10.8 \\
\hline Microsoft & - & - & - & - & - & 9.9 & 6.2 \\
\hline Huawei & 1.1 & 1.5 & 2.3 & 2.7 & 2.9 & 3.8 & 5.9 \\
\hline LG Electronics & 10.1 & 7.1 & 4.9 & 3.3 & 3.8 & 4.0 & 4.0 \\
\hline Lenovo & - & - & - & - & 2.5 & $4.5^{*}$ & $3.7^{*}$ \\
\hline Xiaomi & - & - & - & - & - & 3.0 & 3.6 \\
\hline TCL Communication & - & - & 1.9 & 2.1 & 2.7 & 3.4 & 3.5 \\
\hline Motorola & 4.8 & 2.4 & 2.3 & 1.9 & & - & - \\
\hline HTC & 0.9 & 1.5 & 2.4 & 1.8 & & & \\
\hline Research in Motion & 2.8 & 3.0 & 2.9 & 2.0 & & & \\
\hline ZTE & 1.3 & 1.8 & 3.2 & 3.9 & - & 2.9 & 3.3 \\
\hline Micromax & - & - & - & - & - & 2.0 & 2.2 \\
\hline Sony & 4.5 & 2.6 & - & - & 2.1 & 2.0 & - \\
\hline Yulong & - & - & - & - & 1.8 & & \\
\hline Others & 16.5 & 30.6 & 33.6 & 33.6 & 34.0 & 33.5 & 36.9 \\
\hline
\end{tabular}

Table 6a: Financial Summary of Lenovo (US\$ Million)

\begin{tabular}{|l|r|r|r|r|r|r|r|r|}
\hline & \multicolumn{2}{|c|}{$2012 / 13$} & \multicolumn{2}{|c|}{$2013 / 14$} & Q2 & Q3 & Q4 \\
\hline & Q1 & Q2 & Q3 & Q4 & Q1 & Q \\
\hline Revenue & 8,010 & 8,762 & 9,359 & 7,832 & 8,787 & 9,774 & 10,789 & 9,357 \\
\hline Gross Profit & 1,047 & 1139 & 1,190 & 963 & 1,191 & 1,265 & 1,363 & 1,244 \\
\hline Operating Expenses & -865 & -933 & -947 & -794 & -989 & -982 & -1029 & $-1,013$ \\
\hline Operating Profit & 182 & 206 & 243 & 169 & 202 & 283 & 334 & 231 \\
\hline $\begin{array}{l}\text { Other-Non-Operating } \\
\text { Exp.-Net }\end{array}$ & 3 & -2 & 3 & -3 & 13 & -18 & -13 & -19 \\
\hline Pre-Tax Income & 185 & 204 & 246 & 166 & 215 & 265 & 321 & 212 \\
\hline Taxation & -41 & -41 & -46 & -42 & -45 & -51 & -56 & -44 \\
\hline Profit for the period & 144 & 163 & 200 & 124 & 170 & 214 & 265 & 168 \\
\hline $\begin{array}{l}\text { Non-Controlling } \\
\text { interests }\end{array}$ & -3 & -1 & 5 & 3 & 4 & 6 & 0 & -10 \\
\hline $\begin{array}{l}\text { Profit Attributable to } \\
\text { Equity Holders }\end{array}$ & 141 & 162 & 205 & 127 & 174 & 220 & 265 & 158 \\
\hline EPS (US Cent) & & & & & & & & \\
\hline Basic & 1.37 & 1.58 & 1.99 & 1.22 & 1.67 & 2.12 & 2.56 & 1.53 \\
\hline Diluted & 1.33 & 1.55 & 1.96 & 1.20 & 1.65 & 2.10 & 2.52 & 1.51 \\
\hline Source: Compiled from Annual Reports of Lenovo & & & & \\
\hline
\end{tabular}


Singh N.P.: Lenovo Acquired Motorola Mobility in a Bipolar World of Mobile phone...

Table 6b: Financial Summary of Lenovo (US\$ Million)

\begin{tabular}{|l|r|r|r|r|r|r|r|r|r|}
\hline & \multicolumn{4}{|c|}{$2014 / 15$} & \multicolumn{3}{|c|}{$2015 / 16$} & $2016 / 17$ \\
\hline & Q1 & Q2 & Q3 & Q4 & Q1 & Q2 & Q3 & Q4 & Q1 \\
\hline Revenue & 10,395 & 10,475 & 14,092 & 11,334 & 10,716 & 12,150 & 12,913 & 9,133 & 10,056 \\
\hline $\begin{array}{l}\text { Gross } \\
\text { Profit }\end{array}$ & 1,349 & 1,457 & 2097 & 1,779 & 1,647 & 1575 & 1,885 & 1,518 & 1,538 \\
\hline $\begin{array}{l}\text { Operating } \\
\text { Expenses }\end{array}$ & -1058 & $-1,092$ & -1772 & $-1,652$ & $-1,551$ & $-2,359$ & $-1,506$ & 1,270 & $-1,289$ \\
\hline $\begin{array}{l}\text { Operating } \\
\text { Profit }\end{array}$ & 291 & 365 & 325 & 127 & 96 & -784 & 379 & 248 & 245 \\
\hline $\begin{array}{l}\text { Other-Non- } \\
\text { Operating } \\
\text { Exp.-Net }\end{array}$ & -27 & -36 & -51 & -23 & -55 & -58 & -59 & -55 & -39 \\
\hline $\begin{array}{l}\text { Pre-Tax } \\
\text { Income }\end{array}$ & 264 & 329 & 274 & 104 & 52 & -842 & 320 & 193 & 206 \\
\hline Taxation & -53 & -57 & -17 & -7 & 50 & 125 & -26 & -17 & -38 \\
\hline $\begin{array}{l}\text { Profit for } \\
\text { the period }\end{array}$ & 211 & 272 & 257 & 97 & 102 & -717 & 294 & 176 & 168 \\
\hline $\begin{array}{l}\text { Non- } \\
\text { Controlling } \\
\text { interests }\end{array}$ & 3 & -10 & -4 & 3 & 3 & 3 & 6 & 4 & 5 \\
\hline $\begin{array}{l}\text { Profit } \\
\text { Attributable } \\
\text { to Equity } \\
\text { Holders }\end{array}$ & 214 & 262 & 253 & 100 & 105 & -714 & 300 & 180 & 173 \\
\hline $\begin{array}{l}\text { EPS (US } \\
\text { Cent) }\end{array}$ & & & & & & & & & 1.56 \\
\hline \begin{tabular}{l} 
Basic \\
\hline Diluted
\end{tabular} & 2.06 & 2.52 & 2.32 & 0.91 & 0.95 & -6.43 & 2.71 & 1.63 & 1.57 \\
\hline Source: Compiled from Annual Reports of Lenovo & & & & & & & & & \\
\hline
\end{tabular}


Singh N.P.: Lenovo Acquired Motorola Mobility in a Bipolar World of Mobile phone...

Table 7: Quarterly Global Mobile Market Share by Units (\%age) (2010-2015)

\begin{tabular}{|c|c|c|c|c|c|c|c|c|c|c|c|c|c|c|c|}
\hline Vendors & $\begin{array}{c}\text { Sams } \\
\text { ung }\end{array}$ & $\begin{array}{l}\text { Nokia } \\
\text { IMS }\end{array}$ & $\begin{array}{c}\text { Appl } \\
\mathrm{e}\end{array}$ & $\begin{array}{c}\text { Huaw } \\
\text { ei }\end{array}$ & $\overline{L G}$ & Lenovo & $\begin{array}{c}\text { Xiaom } \\
\text { i }\end{array}$ & $\mathrm{TCL}$ & ZTE & $\begin{array}{l}\text { Micro- } \\
\max \end{array}$ & Sony & HTC & $\begin{array}{l}\mathrm{RI} \\
\mathrm{M}\end{array}$ & $\begin{array}{l}\text { Yul } \\
\text { on }\end{array}$ & Others \\
\hline $2010 Q 1[1]$ & 18.0 & 30.6 & 2.3 & 1.5 & 7.6 & 2.7 & - & - & 1.7 & - & 2.7 & 0.9 & 3.0 & $y$ & 29.0 \\
\hline $2010 Q 2$ [2] & 17.8 & 30.3 & 2.4 & 1.4 & 8.0 & 2.5 & - & - & 1.8 & - & 3.0 & 1.6 & 3.2 & - & 28.1 \\
\hline $2010 Q 3[3]$ & 17.2 & 28.2 & 3.2 & 1.3 & 6.6 & 2.1 & - & - & 1.9 & - & 2.5 & 1.6 & 3.0 & - & 32.5 \\
\hline $2010 Q 4[4]$ & 17.5 & 27.1 & 3.5 & 1.7 & 6.7 & 2.4 & - & - & 2.0 & - & - & 2.0 & 3.3 & - & 33.9 \\
\hline $2011 Q 1$ [1] & 16.1 & 25.1 & 3.9 & 1.6 & 5.6 & 2.1 & - & - & 2.3 & - & 1.9 & 2.2 & 3.0 & - & 36.2 \\
\hline 2011Q2 [2] & 16.3 & 22.8 & 4.6 & 2.1 & 5.7 & 2.4 & - & - & 3.0 & - & 1.7 & 2.6 & 3.0 & - & 35.8 \\
\hline $2011 Q 3[3]$ & 17.8 & 23.9 & 3.9 & 2.4 & 4.8 & 2.5 & - & - & 3.2 & - & 1.9 & 2.7 & 2.9 & - & 33.8 \\
\hline $2011 Q 4$ [4] & 19.4 & 23.4 & 7.4 & 2.9 & 3.6 & 2.1 & - & - & 4.0 & - & - & 2.3 & 2.8 & - & 32.1 \\
\hline $201201[5]$ & 21.1 & 19.7 & 7.8 & 2.6 & 3.5 & 1.4 & - & 1.7 & 4.1 & - & 1.9 & - & - & - & 36.2 \\
\hline $2012 Q 2$ [6] & 21.5 & 19.9 & 6.9 & 2.6 & 3.4 & 1.6 & - & 2.2 & 4.1 & - & 1.7 & - & - & - & 36.1 \\
\hline $2012 Q 3$ [7] & 22.7 & 19.1 & 5.7 & 2.8 & 3.2 & 1.7 & - & 2.2 & 3.9 & - & 1.9 & - & - & - & 36.9 \\
\hline $2012 Q 4[8]$ & 22.0 & 19.1 & 7.5 & 2.7 & 3.3 & 1.6 & - & 2.1 & 3.9 & - & 1.8 & - & - & - & 36.0 \\
\hline 201301 [5] & 23.6 & 14.8 & 9.0 & 2.6 & 3.7 & 1.8 & - & 2.0 & 3.4 & - & 1.9 & - & - & 1.8 & 35.4 \\
\hline $2013 Q 2$ [6] & 24.7 & 14.0 & 7.3 & 2.6 & 3.9 & 2.5 & - & 2.3 & 3.5 & - & 2.2 & - & - & 1.8 & 35.1 \\
\hline $2013 Q 3[7]$ & 25.7 & 13.8 & 6.7 & 3.0 & 4.0 & 2.9 & - & 2.7 & 3.0 & - & 2.1 & - & - & 1.9 & 34.2 \\
\hline $2013 Q 4[8]$ & 24.6 & 13.9 & 8.3 & 2.9 & 3.8 & 2.5 & - & 2.7 & 3.3 & - & 2.1 & - & - & 1.8 & 34.0 \\
\hline $2014 Q 1$ [9] & 24.5 & 11.1 & 9.6 & 3.2 & 3.3 & $3.9^{*}$ & 2.1 & 2.7 & 3.1 & 1.7 & 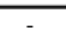 & - & - & - & 34.8 \\
\hline $2014 Q 2$ [10] & 21.9 & 9.9 & 8.0 & 4.1 & 4.1 & $4.3^{*}$ & 2.8 & 3.1 & 2.8 & 1.9 & - & 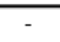 & - & 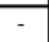 & 37.0 \\
\hline $2014 Q 3$ [11] & 20.6 & 9.5 & 8.4 & 3.6 & 4.2 & $3.3^{*}$ & 3.5 & 3.5 & 3.0 & 2.2 & 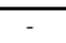 & 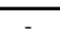 & - & - & 38.2 \\
\hline $2014 Q 4$ [12] & 20.9 & 9.9 & $\begin{array}{c}10 . \\
2\end{array}$ & 3.8 & 4.0 & $4.5^{*}$ & 3.0 & 3.4 & 2.9 & 2.0 & - & - & - & - & 35.5 \\
\hline 201501 [9] & 21.3 & 7.2 & $\begin{array}{c}13 . \\
1\end{array}$ & 4.0 & 4.3 & $4.2^{*}$ & 3.2 & 3.1 & 2.7 & 1.8 & - & - & - & - & 35.2 \\
\hline $2015 Q 2$ [10] & 19.9 & 6.2 & $\begin{array}{c}10 . \\
8\end{array}$ & 5.9 & 4.0 & $3.7^{*}$ & 3.6 & 3.5 & 3.3 & 2.2 & - & - & - & - & 36.9 \\
\hline $2015 Q 3$ [13] & 21.4 & 6.3 & 9.6 & 5.7 & 3.8 & $3.7^{\star}$ & 3.6 & 3.6 & 2.9 & - & - & - & - & - & 39.3 \\
\hline
\end{tabular}


Singh N.P.: Lenovo Acquired Motorola Mobility in a Bipolar World of Mobile phone...

Table 9: Quarterly Global Smartphone Shipments Q2 2014-2015 (Millions of Units)

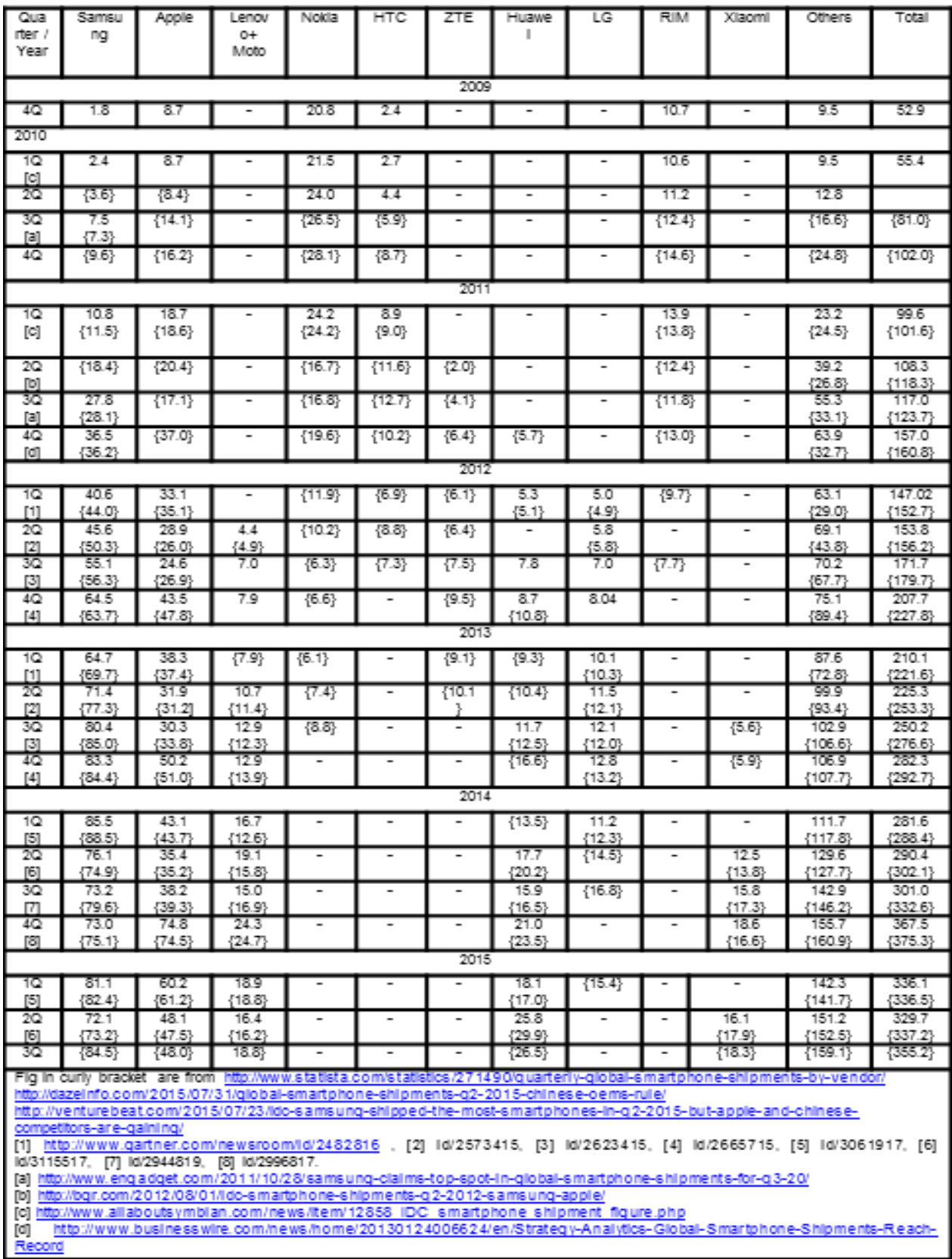

